\title{
ANALYSIS OF THE CULTURAL AND EDUCATIONAL TOURISM DEVELOPMENT IN THE BELGOROD REGION
}

\author{
ANALISE DO DESENVOLVIMENTO DO TURISMO CULTURAL E EDUCACIONAL \\ NA REGIÃO DA BELGOROD
}

\author{
ANÁLISIS DEL DESARROLLO DEL TURISMO CULTURAL Y EDUCATIVO EN LA \\ REGIÓN DE BELGOROD
}

\author{
Elena V. KHARKOVSKAYA ${ }^{1}$ \\ Natalia V. POSOKHOVA ${ }^{2}$ \\ Nina V. EFREMOVA ${ }^{3}$ \\ Elena V. MIROSHNICHENKO ${ }^{4}$
}

\begin{abstract}
Educational tourism is deemed a form of tourism and provides the best education to students learning and improving knowledge. The article deals with the development of cultural and educational tourism. It is noted that at present, cultural and educational tourism is a promising type of domestic tourism. The article's authors argue that the Belgorod region has fairly extensive potential for developing cultural and educational tourism. This, in turn, contributes to the formation of a high cultural level of its inhabitants, health improvement and recreation of the population, and also generally positively affects the economy of the regions through the competent use of the recreational potential and contributes to solving the problem of employment in small towns and settlements. The Questionnaire research is conducted to meet that aim. It can be concluded that cultural and educational tourism can be developed using an innovative method as a quest excursion.
\end{abstract}

KEYWORDS: Educational tourism. Knowledge. Domestic tourism. Quest excursion.

RESUMO: O turismo educativo é considerado uma forma de turismo e proporciona a melhor educação aos alunos, aprendendo e aprimorando conhecimentos. $O$ artigo trata do desenvolvimento do turismo cultural e educacional. De referir que, atualmente, o turismo cultural e educacional é uma forma promissora de turismo doméstico. Os autores do artigo argumentam que a região de Belgorod tem um potencial bastante amplo para o desenvolvimento do turismo cultural e educacional. Que, por sua vez, contribui para a formação de um elevado nível cultural dos seus habitantes, melhorias na saúde e lazer da

\footnotetext{
${ }^{1}$ Belgorod State Institute of Arts and Culture, Belgorod - Russia. PhD in Pedagogy, Associate Professor of the Department of Social and Cultural Activities and Tourism. ORCID: https://orcid.org/0000-0002-4942-5830. Email: elena.xarkovskaya@mail.ru

${ }^{2}$ Belgorod State Institute of Arts and Culture, Belgorod - Russia. PhD in Sociology, Associate Professor, Professor of the Department of Social and Cultural Activities and Tourism. ORCID: https://orcid.org/0000-0001-5834885X. E-mail: natalina 76@mail.ru

${ }^{3}$ Belgorod State Institute of Arts and Culture, Belgorod - Russia. PhD in Pedagogy, Associate Professor, Professor of the Department of Social and Cultural Activities and Tourism. ORCID: https://orcid.org/0000-0002-2791-8562. E-mail: skibd@bgiik.ru

${ }^{4}$ Belgorod State Institute of Arts and Culture, Belgorod - Russia. PhD in Pedagogy, Associate Professor. ORCID: https://orcid.org/0000-0002-3699-8963. E-mail: info@prescopus.com
} 
população, e também, geralmente, afeta positivamente a economia das regiões através do aproveitamento competente do potencial recreativo e contribui para a resolução do problema de emprego em pequenas cidades e assentamentos. A pesquisa do Questionário é conduzida para atender a esse objetivo. Pode-se concluir que o turismo cultural e educacional pode ser desenvolvido utilizando um método inovador como uma excursão de busca.

PALAVRAS-CHAVE: Turismo educacional. Conhecimento. Turismo doméstico. Excursão de busca.

RESUMEN: El turismo educativo se considera una forma de turismo y proporciona la mejor educación a los estudiantes que aprenden y mejoran el conocimiento. El artículo trata sobre el desarrollo del turismo cultural y educativo. Se observa que en la actualidad, el turismo cultural y educativo es un tipo de turismo interno prometedor. Los autores del artículo argumentan que la región de Belgorod tiene un potencial bastante amplio para desarrollar el turismo cultural y educativo. Esto, a su vez, contribuye a la formación de un alto nivel cultural de sus habitantes, mejora de la salud y recreación de la población, y además, en general, afecta positivamente la economía de las regiones a través del uso competente del potencial recreativo y contribuye a la solución del problema de empleo en pequeñas ciudades y asentamientos. La investigación del Cuestionario se realiza para alcanzar ese objetivo. Se puede concluir que el turismo cultural y educativo se puede desarrollar utilizando un método innovador como excursión de búsqueda.

PALABRAS CLAVE: Turismo educativo. Conocimiento. Turismo interno. Excursión de búsqueda.

\section{Introduction}

Belgorod Region has all the conditions for the dynamic development of domestic and inbound tourism. The Belgorod region is characterized by the diversity of cultures (for example, Proto-Slavic, Ryumensky, Russian, Old Russian, Saltovo-Mayak), which is justified by the historical development and formation, as well as the favourable natural and climatic conditions of the region (for example, the rivers belonging to the basin of the Dnieper and the Don, pine forests and oak groves, forest-steppe and steppe zone).

Cultural and educational tourism in the Belgorod region contributes to the formation of a high cultural level of its inhabitants, health and recreation of the population, as well as a generally positive effect on the regional economy through the competent use of recreational potential and contributes to solving the employment problem in small towns and settlements (NIKOLAYEVA, 2002).

At the moment, cultural and educational tourism in the Belgorod region involves a large part of school groups, which is about $70 \%$ of the total population at a rough guess. Local residents prefer rather spend vacations with their families, so the direction of "family tourism" 
becomes promising. Also, the advertising and information support of enterprises and tourism organizations in the Belgorod region will contribute to the development of cultural and educational tourism among the whole population, and attract tourist flows from other regions of Russia and the world (ROMANENKO; VASILYEVA, 2006).

Cultural and educational tourism is developing gradually in the Belgorod region. In general, we can say that this type of tourism is developing at a gradual pace. There are enterprises that are ready to present various excursion programs in the Belgorod region.

The Belgorod region has quite a vast potential for the development of cultural and educational tourism. Various tourist enterprises can offer a huge range of excursion programs from small to large. For example, there are organizations that specialize mainly in domestic and inbound tourism in the Belgorod Region. These organizations include: the tourist bureau "Dobrokhot", the bureau of fine excursions "Promenade", the Centre for Tourism Development and Folk Arts and Crafts "Zolotaya Podkova", the Belgorod Regional Centre for Children's and Youth Tourism and Excursions.

There are also organizations that are ready to offer both outbound and inbound touristic tours, offering weekend tours and small excursion programs. Some travel companies, such as "Active-tour", "Tour Centre Expo", "Centre of Peace", "Colibri-tour", "Nika Tour" and others.

Let us take a closer look at the proposals for the implementation of cultural and educational tourism in Belgorod region. To analyze tourist products in the Belgorod region, we considered such organizations as the tourist bureau "Dobrokhot", the bureau of fine excursions "Promenade", the Centre for Tourism Development and Folk Arts and Crafts "Zolotaya Podkova", the Belgorod Regional Centre for Children and Youth Tourism and Excursions; tourist companies "Activ-tour", "Kolibri-tour", "Nika Tour" and "Centre of Peace".

1. Tourist Bureau "Dobrokhot" is ready to offer cultural and educational tours aimed at corporate recreation (10 tours) and schoolchildren (17 tours) on the places of military glory of the Russian army, in unique protected areas, Centers of folk art and culture, craft tours to the masters' estates with master classes ${ }^{5}$. Excursion programs in the Belgorod region and the city of Belgorod are presented in Table 1.

${ }^{5}$ More on this subject: https://Dobrokhot31.com. Access: 10 Jan. 2021. 
Table 1 - Cultural and educational tours organised by the tourist bureau "Dobrokhot"

\begin{tabular}{|c|c|}
\hline Corporate vacations in Belgorod region & School trips to the Belgorod region \\
\hline $\begin{array}{c}\text { 1) Tour over the Belgorod region (Belgorod and its } \\
\text { districts - Prokhorovsky, Chernyansky, Rakityansky, } \\
\text { Graivoronsky and Borisovsky, as well as the town of } \\
\text { Novy Oskol) }\end{array}$ & $\begin{array}{c}\text { 1) "The Third Battlefield of Russia". } \\
\text { (State Historical and Military Reserve Museum } \\
\text { "Prokhorov Field") }\end{array}$ \\
\hline $\begin{array}{l}\text { 2) weekend hiking tour (walking excursion along the } \\
\text { forests to the Koren river with lunch) }\end{array}$ & $\begin{array}{l}\text { 2) "History and traditions of Belgorodchina } \\
\text { (Belgorod land)" (regional park "Klyuchi", } \\
\text { ancestral estate "Dubrava") }\end{array}$ \\
\hline $\begin{array}{l}\text { 3) Visit to real Cossacks! (Cossack camp "Sosnovoye" } \\
\text { situated on the outskirts of Novy Oskol between pine } \\
\text { forests and the river) }\end{array}$ & $\begin{array}{l}\text { 3) Excursion to Prokhorovka District (familiarizing } \\
\text { with the Kasatonov dynasty of naval commanders, } \\
4 \text { exhibition halls with unique exhibits and a } \\
\text { realistic picture of the Soviet Navy era) }\end{array}$ \\
\hline 4) Holy Trinity Monastery in the village Kholki & $\begin{array}{l}\text { 4) "The beauty of Belgorodchina traditions" } \\
\text { (village Tomarovka, cheese museum, Borisov } \\
\text { ceramics, "Forest on Vorskla" and the zoo of } \\
\text { sanatorium "Krasivo") }\end{array}$ \\
\hline $\begin{array}{l}\text { 5) "Prokhorovskoe Pole" (The State Military Historical } \\
\text { Museum Reserve "Prokhorovka Field") }\end{array}$ & $\begin{array}{l}\text { 5) "Wildlife sanctuary parts " (Graivoron, "Ptychiy } \\
\text { ray" ("Bird Paradise"), Golovchino village } \\
\text { "Krugloye zdaniye", "Petrovskaya Krucha") } \\
\end{array}$ \\
\hline $\begin{array}{l}\text { 6) "Wildlife sanctuary parts " Graivoron ("Bird } \\
\text { Paradise", Golovchino village "Krugloye zdaniye" } \\
\text { ("Round Building"), "Petrovskaya Krucha") }\end{array}$ & $\begin{array}{l}\text { 6) Excursion to the Rakitnoe district (Rakitnoe } \\
\text { village - the palace complex of the Yusupov } \\
\text { Knyazs, the ostrich farm in the village Bobrava) }\end{array}$ \\
\hline $\begin{array}{l}\text { 7) "History and traditions of Belgorodchina" (the mill } \\
\text { of the merchant Barkov, the reserve "Bekaryukovsky } \\
\text { bor (pine forest)", the church in the village of } \\
\text { Zimovenki or "Yasny kolodets" ("Clear well") and the } \\
\text { museum of the First Cavalry Army) }\end{array}$ & $\begin{array}{l}\text { 7) Excursion to Chernyansk rayon (excursion to the } \\
\text { underground monasteries, the spring "Yasny } \\
\text { kolodets" ("Clear well")) }\end{array}$ \\
\hline $\begin{array}{l}\text { 8) "The beauty of Belgorodchina traditions" (Rakitnoe } \\
\text { village - the palace complex of the Yusupovs' Knyazs, } \\
\text { the ostrich farm in the village Bobrava) }\end{array}$ & $\begin{array}{c}\text { 8) excursion to Shebekinsky region (village } \\
\text { Kupino, a story about the history of folk culture, } \\
\text { visit of farmsteads, master classes on weaving and } \\
\text { pottery) }\end{array}$ \\
\hline $\begin{array}{l}\text { 9) excursion to the Yakovlevsky District (memorial } \\
\text { devoted to the Kursk Battle, museum named after M.S. } \\
\text { Schepkin with a master class) }\end{array}$ & $\begin{array}{l}\text { 9) excursion to the Volokonovsky area (the mill of } \\
\text { the merchant Barkov, the reserve "Bekaryukovsky } \\
\text { Bor" (pine forest), the temple in the village } \\
\text { Zimovenki or "The Clear Well" and the museum of } \\
\text { the First Cavalry Army) }\end{array}$ \\
\hline \multirow[t]{3}{*}{$\begin{array}{l}\text { 10) "The saving castle "Novy Ierusalim" (" New } \\
\text { Jerusalem ") (village Sukharevo - "New Jerusalem") }\end{array}$} & $\begin{array}{c}\text { 10) Excursion to the Yakovlevsky District } \\
\text { (memorial dedicated to the Battle of Kursk, } \\
\text { museum named after M. S. Schepkin with a master } \\
\text { class) }\end{array}$ \\
\hline & $\begin{array}{l}\text { 11) Excursion to the town of Novy Oskol (Cossack } \\
\text { camp "Sosnovoye" on the outskirts of Novy Oskol }\end{array}$ \\
\hline & $\begin{array}{l}\text { 12) Excursion to Stary Oskol (a story about the } \\
\text { history of the fortress Oskol, acquaintance with the } \\
\text { clay toys of Stary Oskol and the secrets of } \\
\text { craftsmen at the House of Crafts) }\end{array}$ \\
\hline
\end{tabular}




\begin{tabular}{|l|c|}
\hline & $\begin{array}{c}\text { 13) Excursion to Valuysky district (visiting the } \\
\text { church, monastery and museum, a story about the } \\
\text { history of the city) }\end{array}$ \\
\hline & $\begin{array}{c}\text { 14) Excursion to the city of Belgorod (airport } \\
\text { museum, familiarizing with passport and customs } \\
\text { control, the runway, and the airplane, subject to the } \\
\text { availability of the airplane on the runway) }\end{array}$ \\
\hline $\begin{array}{c}\text { 15) Excursion to the town of Gubkin (Gubkin, } \\
\text { museum of KMA and the observation platform of } \\
\text { the Mining and Processing Factory) }\end{array}$ \\
\hline $\begin{array}{c}\text { 16) Field trip to Belgorod (history of Belgorod, } \\
\text { visiting of emblematic places) }\end{array}$ \\
\hline $\begin{array}{c}\text { 17) Tour around the Belgorod region (Belgorod and } \\
\text { its districts - Prokhorovsky, Chernyansky, } \\
\text { Rakityansky, Graivoronsky and Borisovsky, as well } \\
\text { as from Novy Oskol) }\end{array}$ \\
\hline
\end{tabular}

Source: Devised by the authors

2. Bureau of Fine Excursions "Promenade" develops interesting excursions for the population and visitors to Belgorod. The organization offers six excursion programs. During the excursions and walks, tourists are given information not only about the history of Belgorod, milestones of its formation and managers, but also about the city today, its inhabitants, new projects, and interesting facts (MATVEEVA, 2014).

Bureau of Fine Excursions "Promenade" offers the following excursion programs:

1) Belgorod by car: a story about the main sights of the city, its history and the present day, visiting the Cathedral Square and the Square of Three Museums, a ride to the Kharkov Hill, and a visit to the observation deck with a monument to Knyaz Vladimir.

2) Cultural Belgorod: a story about modern cultural Belgorod, a visit to the Square of Three Museums and a story about old theatrical legends, a walk along Grazhdansky Avenue with a story about Imperatorskaya Street, and cultural events of the city.

3) Belgorod for men: a walk around Belgorod in cars with a story about a beer factory, bathhouses, and taverns.

4) Romantic Belgorod: a story about romantic legends, gifts when meeting in the past, a walk along the most romantic street of the city.

5) Orthodox Belgorod: interesting facts about active churches, a story about those who created the Marfo-Mariinsky monastery and other shrines of Belgorodchina; about the fate of Orthodox structures that have not survived to this day.

6) Instagram-Belgorod: a story about interesting facts about the city from the area of "Knyaz Vladimir" up to the Square, a walk through the most "photogenic" places of Belgorod. 
3. The Centre for Development of Tourism and Folk Arts and Crafts "Zolotaya Podkova" offers a variety of cultural and educational weekend tours in the Belgorod region. Its programs include: "Prokhorovskaya Sloboda", "Borisovskaya and Grayvoronskaya Sloboda", "Tales and Legends of the Land of Belgorod. Novooskolsky District", "Legends of the Land of Belgorod. Rakitnaya Sloboda", and others (Excursion routes in the Belgorod region).

4. The Belgorod Regional Centre for Children and Youth Tourism and Excursions offers a wide range of cultural and educational programs aimed primarily at the younger generation, i.e., schoolchildren. The organization develops and organizes various thematic excursions in Belgorod region (23 tours) and the city of Belgorod (14 tours), and also two-day sightseeing and local history programs ( 3 tours). They are in great demand among the population of the city of Belgorod and require special attention to the safety of travel arrangements for schoolchildren.

Cultural and educational programs, which are implemented by the Belgorod Regional Centre for Children and Youth Tourism and Excursions, cover a huge number of cultural and historical, and also natural sites, monuments of architectural heritage and modernity, introduce the younger generation to Belgorod Region, and have an educational component ${ }^{6}$. Excursion programs offered by the Centre for Children and Youth Tourism and Excursions are presented in Table 2.

Table 2 - Cultural and educational tours organized by the Belgorod Regional Centre for Children and Youth Tourism and Excursions

\begin{tabular}{|c|c|c|}
\hline $\begin{array}{c}\text { Excursions to the Belgorod } \\
\text { region }\end{array}$ & Trips to Belgorod & $\begin{array}{c}\text { Two-day excursion and local } \\
\text { history programs }\end{array}$ \\
\hline $\begin{array}{c}\text { 1) Thematic excursion "In honor } \\
\text { of the heroes of the Kursk Battle }\end{array}$ & $\begin{array}{c}\text { 1) Sightseeing tour of Belgorod with a } \\
\text { visit to one (two) excursion sites }\end{array}$ & $\begin{array}{c}\text { 1) "Visit the capital of } \\
\text { Belogorye" excursion } \\
\text { program }\end{array}$ \\
\hline $\begin{array}{c}\text { 2) Thematic excursion } \\
\text { "Prokhorovka field }\end{array}$ & 2) Thematic excursion "My White City & $\begin{array}{c}\text { 2) Excursion program } \\
\text { "Belgorod scorched by war". }\end{array}$ \\
\hline $\begin{array}{c}\text { 3) Thematic excursion "In the } \\
\text { places of fights at the Kursk } \\
\text { Salient". }\end{array}$ & $\begin{array}{c}\text { 3) Thematic excursion "The Saint man, } \\
\text { who glorified Belgorod for Ages". }\end{array}$ & $\begin{array}{c}\text { 3) Excursion program "The } \\
\text { future of Belgorod region in } \\
\text { your hands". }\end{array}$ \\
\hline $\begin{array}{c}\text { 4) Thematic excursion } \\
\text { "Prokhorovka district estates - } \\
\text { "Klyuchi" and "Dubrava }\end{array}$ & $\begin{array}{c}\text { 4) Thematic excursion "Temples of } \\
\text { Belgorod". }\end{array}$ & \\
\hline $\begin{array}{c}\text { 5) Thematic excursion } \\
\text { "Borisovka - settlement of } \\
\text { soldiers, potters, and icon painters }\end{array}$ & $\begin{array}{c}\text { 5) Thematic excursion "Belgorod } \\
\text { scorched by war". }\end{array}$ & \\
\hline $\begin{array}{c}\text { 6) Thematic excursion } \\
\text { "Borisovka - nature reserve" }\end{array}$ & $\begin{array}{c}\text { 6) Thematic excursion "Sacred springs } \\
\text { of Belogorie" }\end{array}$ & \\
\hline
\end{tabular}

${ }^{6}$ More on the subject: http://www.belcdtur.ru. Access: 10 Jan. 2021. 


\begin{tabular}{|c|c|c|}
\hline $\begin{array}{l}\text { 7) Thematic excursion "The } \\
\text { ancient city-fortress of } \\
\text { Khotmyzhsk }\end{array}$ & $\begin{array}{l}\text { 7) Thematic excursion "Back to } \\
\text { dinosaurs }\end{array}$ & \\
\hline $\begin{array}{l}\text { 8) Thematic excursion } \\
\text { "Graivoron - the Pearl of } \\
\text { Belogorye }\end{array}$ & $\begin{array}{l}\text { 8) Thematic excursion "From Carting - } \\
\text { to Formula 1" }\end{array}$ & \\
\hline $\begin{array}{l}\text { 9) Thematic excursion "The } \\
\text { Round Building Mystery" }\end{array}$ & $\begin{array}{l}\text { 9) Thematic excursion "The birth of } \\
\text { photo" }\end{array}$ & \\
\hline $\begin{array}{l}\text { 10) Thematic excursion "The } \\
\text { Farm at Grany" (Grayvoron } \\
\text { region) }\end{array}$ & $\begin{array}{c}\text { 10) Thematic excursion "Green light to } \\
\text { young Belgorod citizens". }\end{array}$ & \\
\hline $\begin{array}{l}\text { 11) Thematic excursion } \\
\text { "Shebekino city - the past, the } \\
\text { present, the future" }\end{array}$ & $\begin{array}{l}\text { 11) Thematic excursion "Tasty } \\
\text { excursion around Belgorod". }\end{array}$ & \\
\hline $\begin{array}{l}\text { 12) Thematic excursion "Centre } \\
\text { of national culture of the village } \\
\text { Kupino" }\end{array}$ & $\begin{array}{l}\text { 12) Thematic excursion "Journey to the } \\
\text { fantastic world" }\end{array}$ & \\
\hline $\begin{array}{l}\text { 13) Thematic excursion "County } \\
\text { patio in the town of Korocha". }\end{array}$ & $\begin{array}{l}\text { 13) Thematic excursion "Airport: } \\
\text { Belgorod and world capitals" }\end{array}$ & \\
\hline $\begin{array}{l}\text { 14) Thematic excursion "Holy } \\
\text { Trinity Kholkovo underground } \\
\text { monastery". }\end{array}$ & $\begin{array}{l}\text { 14) Thematic excursion "Dessert } \\
\text { stories" }\end{array}$ & \\
\hline $\begin{array}{l}\text { 15) Thematic excursion "To the } \\
\text { motherland of M.S. Shchepkin" }\end{array}$ & & \\
\hline $\begin{array}{l}\text { 16) Thematic excursion "The } \\
\text { Yusupovs' Estate" }\end{array}$ & & \\
\hline $\begin{array}{l}\text { 17) Thematic excursion "The } \\
\text { Third Magnetic Pole of the Earth" }\end{array}$ & & \\
\hline $\begin{array}{l}\text { 18) Thematic excursion "In the } \\
\text { birthplace of the Decembrist poet } \\
\text { V.F. Rayevsky" }\end{array}$ & & \\
\hline $\begin{array}{l}\text { 19) Thematic excursion "Old } \\
\text { Oskol" }\end{array}$ & & \\
\hline $\begin{array}{l}\text { 20) Thematic excursion "In the } \\
\text { birthplace of the poet V.Y. } \\
\text { Eroshenko }\end{array}$ & & \\
\hline $\begin{array}{l}\text { 21) Thematic excursion } \\
\text { "Historical and cultural cave } \\
\text { complex of Ignatius God-bearer } \\
\text { (Ignatiy Bogonosets) }\end{array}$ & & \\
\hline
\end{tabular}

Source: Devised by the authors

5. Tourist company "Active-tour" is ready to offer cultural and educational tours for schoolchildren, students, and any organizations. A huge number of various excursion programs is based on the implementation of cultural objects of each city of Belgorod region (22 excursions) (Excursion tours across the Belgorod region). The organization implements the following cultural and educational tours:

1) Solnechny Krai (Alekseevka). 
2) $\mathrm{OAO}$ "Belgorod cold storage facility" (Belgorod).

3) "Biryuch Trade Rows" (Biryuch).

4) "Borisovka - its past and present" (Borisovka).

5) "Spiritual Heritage of Valuisky District" (town of Valuiki).

6) "Vorontsovsky Krai" (Veydelevka).

7) "History of Volokonovskiy District" (town of Volokonovka).

8) "Grayvoron and its legends..." (town of Grayvoron).

9) "Gubkin - Centre of attraction" (town of Gubkin).

10) "Little Switzerland" (Ivnya).

11) "Konshino - land of masters" (Konshino, Gubkinsky district).

12) "Korocha - apple land" (Korocha town).

13) "Trip to Krasnoe" (settlement Krasnoe).

14) "Beautiful area" (Krasnaya Yaruga).

15) "Visit to the Cossacks! (Novy Oskol).

16) "Homesteads, Klyuchi, Dubrava and Russkoe Podvorye" (Prokhorovka settlement).

17) "Rakityansky District" (Rakitnoe settlement).

18) "Walk around Rovenky" (Rovenky settlement).

19) "Starooskolye" (town of Stary Oskol).

20) "In the footsteps of the Greats" (town of Stroitel).

21) "Kholkovo cave monastery" (Chernyanka settlement).

22) "Kupino - the centre of traditional culture" (Shebekino).

6. Tourist company "Kolibri-tour" is aimed at the implementation of outbound, inbound, and domestic tourism. The organization offers to meet and acquaint the guests of the city with various cultural sights with the help of excursions (12 excursions) ${ }^{7}$. The tourist company "Kolibri-tour" offers the following excursion programs:

1) "Memorial Complex" - in honor of the heroes of the Kursk Battle (Yakovlevsky district).

2) Museum - Reserve "Prokhorovskoe Pole" (Bell Tower, Peter and Paul Church, N. Ryzhkov library, museum). 
3) Memorial Complex "In honour of the heroes of the Kursk Battle" and Museum Reserve "Prokhorovskoe Pole" (memorial, bell tower, Church of Peter and Paul, N. Ryzhkov library).

4) OOO "Borisov ceramics" (ceramics store, "Forest on Vorskla", museum of the reserve).

5) Shebekino (sightseeing tour, historical and artistic museum);

6) Kholkovo caves (Chernyansk district).

7) Reserve "Belogorye" (Borisov district).

8) Historical and cultural Centre - the village of Kupino, Shebekinsky district.

9) Rakitnoe (manor of Knyazs Yusupovs, Svyatolsky church).

10) Museum of the Decembrist V.F. Rayevsky (Gubkin district), Gubkin - museum of local lore and sightseeing.

11) To the Great Actor Mikhail Shchepkin's homeland (Yakovlevsky district).

12) Graivoron (building "Krugloe", spiritual and educational Centre, zoo, pancakes tasting).

7. Travel company "Nika Tour" is ready to offer tourists several one-day tours ( 9 excursions), implementing domestic tourism and various tours of inbound tourism ( 6 tours $)^{8}$. These tourist products are presented in table 3 .

Table 3 - Cultural and educational tours organized by Nika tour company

\begin{tabular}{|c|c|}
\hline One-day tours & Reception in Belgorod \\
\hline 1) Circular Building & 1) Belgorod - City of Military Glory \\
\hline 2) Sightseeing tour & 2) Holy Belogorye \\
\hline 3) Ethno-village on the Psel river & 3) Patrimonial Estates \\
\hline 4) Prokhorovka field & 4) Tour for school groups \\
\hline 5) Kholkinskie caves & 6) One-day excursions \\
\hline 6) Borisov ceramics and cheese & \\
\hline 7) Museum of M.S. Schepkin & \\
\hline 8) Museum of folk crafts & \\
\hline 9) Yusupovs estate and ostrich farm &
\end{tabular}

Source: Devised by the authors

8. Tourist company "Tsenter Mira" offers various tours on inbound tourism and tourism of the Belgorod region (Rest according to the directions - Excursions). The organization sells various bus tours, such as:

1) The park of regional significance "Klyuchi" and the manor "Dubrava".

${ }^{8}$ More information at: http://www.nikatur31.ru. Access: 10 Jan. 2021.

RPGE- Revista on line de Política e Gestão Educacional, Araraquara, v. 25, n. esp. 6, p. 3550-3567, Dec. 2021. e-ISSN:1519-9029 
2) Along the holy places of Belogorie with a visit to the Holy Nicholas Cathedral of the Assumption Nicholas Monastery, the Church of Ignatius Bogorodets, the entrance to the cave church, the Temple of Nativity in the village Rozhdestvenno, the Church of the Znamenskaya Icon of God in the village Urazovo, the Temple "New Jerusalem" in the village Sukharevo, the Architectural Complex "Verigovsky spring" in the village Verigovka.

3) Forest on the Vorskla River and the Belgorod Reserve with a visit to the museum "Cheese House" with a master class on cheese making, the reserve "Belogorye", the town of Khotmyzhsk, a monument of Slavic-Russian culture "Khotmyzhskoe settlement", and the Church of the Resurrection.

The range of excursion programs offered for tourists to visit cultural sites is quite large. But, unfortunately, none of them is engaged in the development and organization of quest tours, but only cultural and educational tours and excursions.

Thus, having analyzed the activities of tourist enterprises in the Belgorod region for the development of cultural and educational tourism, we found out that there is a need to find new forms of work, as well as to popularize the existing activities of tourist enterprises in the region for the development of cultural and educational tourism by means of quest excursions, taking into account the interests and needs of the younger generation.

In the course of our study, we have identified organizations that are able to offer questexcursions in the Belgorod region. The results showed that from the scientific point of view, quest-excursions for young people have not been studied enough. In general, there are only sporadic publications in scientific journals and descriptions of their organization on the websites.

In general, the quest excursions as a new tourist product should be presented in the tourist market, including their introduction in the excursion programs with the aim of developing cultural and educational tourism. This will contribute to the development of the region as a whole, its economy, and infrastructure, and attracting the attention of the younger generation of the Belgorod region and visitors to the study of culture, art, and traditions of their native land.

When creating a new tourist product, a huge role is played, first of all, by the interest of people and the possibility of its implementation, as well as the definition of the target audience.

In this regard, we conducted a sociological study with the help of questionnaires aimed at studying the status, trends, and prospects of development of cultural and educational tourism by means of quest tours among young people in Belgorod. Questioning is a fairly effective way of scientific research, through which we can get the most complete analysis concerning the 
interest of the younger generation of tourists in quest-excursions in the Belgorod region (BARCHUKOV, 2008).

In order to fully determine the quality of services, we have compiled a questionnaire of 12 questions and conducted a study of demand among young people for quest-excursions in the Belgorod region. In the process of the survey, we interviewed 100 people from different spheres of activity among the students of the Belgorod State Institute of Arts and Culture and tourists from travel agencies in Belgorod city. This questionnaire was conducted through a personal and e-mail survey of respondents. The results of the answers to the questions are presented in the form of diagrams and tables.

The following data were obtained during the questionnaire survey:

An answer to the questionnaire question "Do you know that there are quest-excursions in Belgorod region?" consists in the analysis of popularity and publicity of quest-excursions in the Belgorod region among young people and allows us to understand the level of development of this direction in the region. Answer options of the questionnaire survey were also intended to find out whether any of the respondents took part in quest-excursions and their subjective opinion about it.

The results showed that most of the respondents answered that they are aware of questexcursions in the Belgorod region, but do not participate (53 people). We assume that this is because the direction itself and its coverage in the media are not developed, as this implies the following response option, which gained the majority of answers given by the second half of the respondents: 24 people have previously heard something about the quest-excursions held in Belgorod region. Due to the low coverage of quest excursions as a new type of tourism, the following group of young people appears who answered that they do not know about their conduct in the Belgorod region but would like to participate (11 people). An equal number of young people ( 6 persons) gave the answers that they know and participate with pleasure in quest-excursions, and they do not know about holding them in the Belgorod Region and do not want to participate in them, because it is not interesting - 6 people (see Fig. 1). 
Figure 1 - Distribution of answers to the question "Do you know that quest excursions are held in the Belgorod region?"

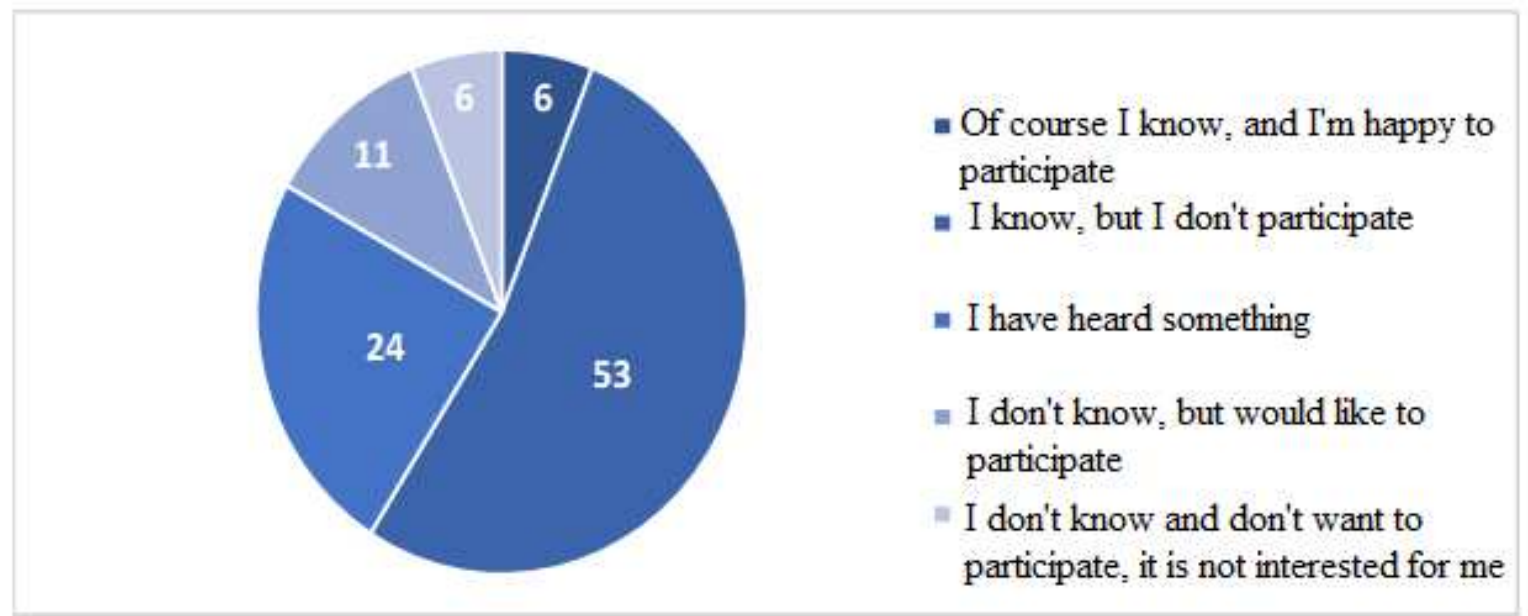

Source: Devised by the authors

In the course of answering to the following question "Please indicate, what price per participant of a quest-excursion would seem optimal to you" among the 100 respondents questioned, different price per participant of the quest-excursion was indicated. The lowest price was 100 rubles and the highest was 1000 rubles. We put together similar answers and the following results are obtained (see Fig. 2).

Figure 2 - Distribution of answers to the question "Please, specify what price per participant of the quest-excursion would seem optimal to you"

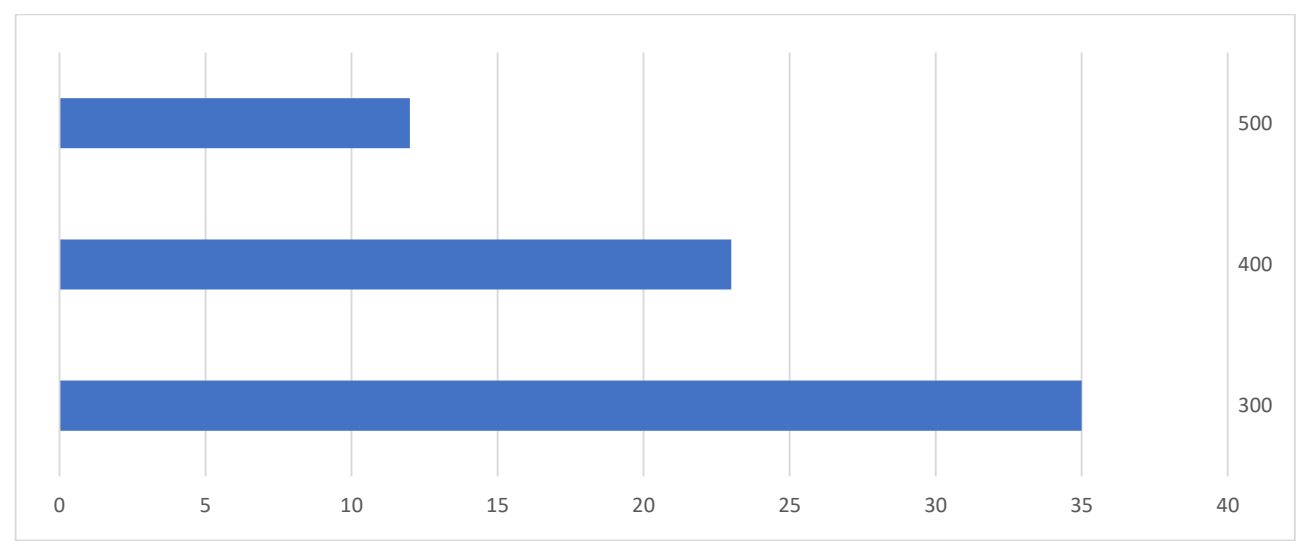

Source: Devised by the authors 
According to the answer to the question, 78 respondents estimated the price of a quest excursion from 300 to 500 rubles, while the remaining 22 respondents did not repeat and indicated the cost from 100 to 1000 rubles. Thus, the most optimal price for a quest excursion is between 300 and 500 rubles.

Based on the results of the seventh, eighth and ninth questions, it is possible to recommend the developers of Belgorod region quest-excursions the cost of 300, 500 and 700 rubles per person.

As a result of respondents' answers to the next question of the questionnaire "Tell us, what is the degree of probability that you will give preference to a quest-excursion when choosing a weekend recreation?" we found out that 18 people are not likely to choose a questexcursion as a weekend recreation, 38 people are unlikely to prefer this type of recreation, 29 people may want to choose it. It is very likely that 12 respondents will take part in a quest excursion, and 3 people will definitely choose a quest excursion as a weekend recreation (see Figure 3).

Figure 3 - Distribution of answers to the question "Tell me, what is the degree of probability that you will give preference to a quest-excursion when choosing a type of recreation for the weekend?"

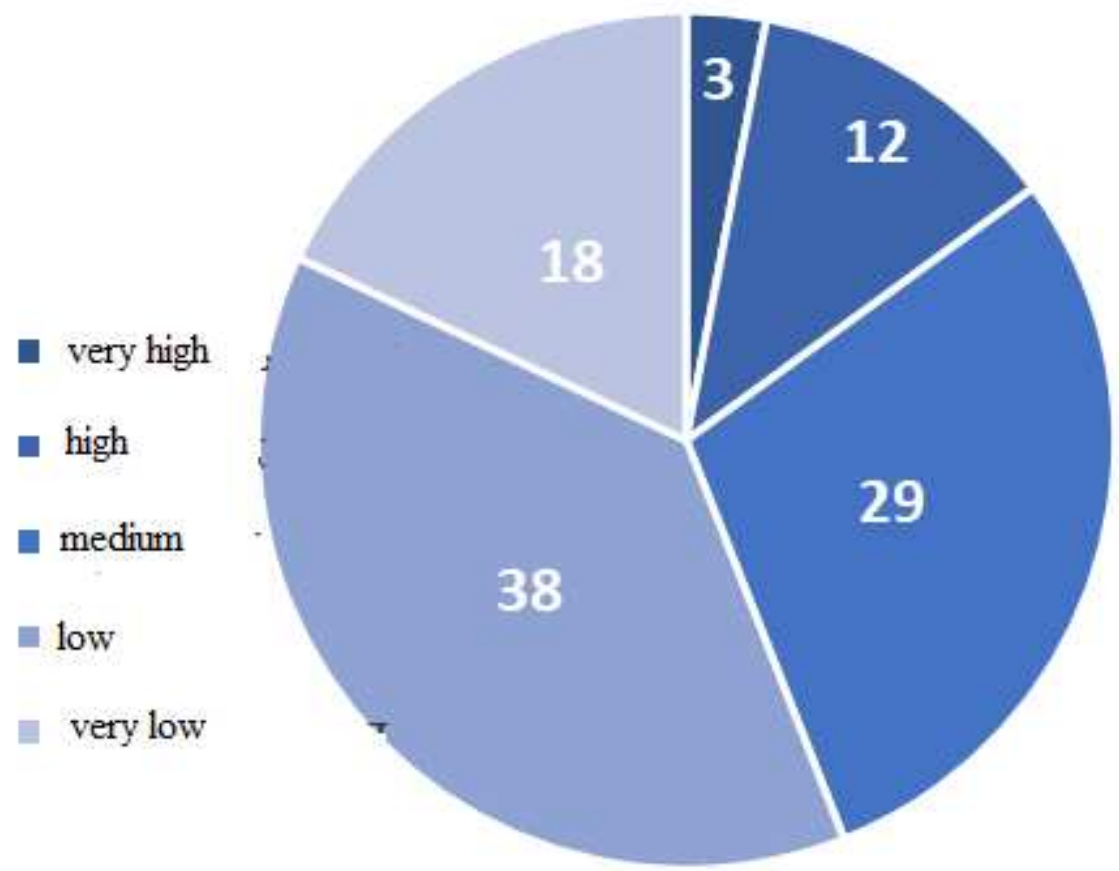

Source: Devised by the authors 
To summarize, we can call the questionnaire a very effective practical method in the study of youth demand for participation in quest-excursions. Drawing conclusions from the survey, we would like to note that 100 people were interviewed. Young people aged 17 to 35 years participated in this survey.

The results showed that not many young people are aware that Belgorod region organizes quest-excursions; few of them have participated and know that this is a new type of cultural and educational tourism. Just because of this, quest excursions as a new direction are worth developing, because young people are interested in innovations. There is already a demand for the quest excursions, so tourist organizations need to take this into account and develop this direction.

In connection with the analysis of the younger generation's interest in quest excursions, we have developed a quest excursion "Artefacts of Belgorod". This quest-excursion is aimed at the development of human personality, his/her intellectual abilities, communication skills, teamwork, and general psycho-physical relief.

At the end of the tour the excursionists are invited at each stage of the quest-excursion to briefly examine the object of the show on their own and take a photo as a memento.

Purpose of an excursion: to develop cultural and educational tourism among different categories of people by synthesizing the excursion part with game tasks, which will contribute to a more successful perception of information, multilateral development of man, and give general physical and emotional relief.

Objectives of an excursion:

1. To familiarize participants with the history and sights of the central part of Belgorod, with its monuments of culture and history, and with the objects of architectural heritage.

2. To promote obtaining an additional knowledge about the history of Belgorod in the prewar and postwar periods.

3. To develop intellectual potential of participants by means of realization of the knowledge received by them in solution of various tasks.

4. To unite a group of people into one team, developing their communicability and initiative in solving questions.

5. To give general physical and emotional relief to each person with the help of game tasks.

Type of excursion:

By content: thematic.

According to the travel method: pedestrian. 
By location: Grazhdansky Avenue, Belgorod.

By composition and number of participants: group.

Duration of the tour: 4 hours 45 minutes with a break for lunch in the municipal cafe "Orion".

Excursion category: university students, high school students, young and middle-aged population of Belgorod.

The main objects of the show:

- Memorial Cross in honor of Cyril and Methodius;

- A. A. Likhanov Children's Library;

- Monument to geodesist and Weinbaum;

- Monument to S. Degtyarev;

- Municipal Cafe "Orion" and the Alley of Friendship of Peoples;

- Cathedral Square and the M.S. Schepkin Drama Theater;

- Square at the Drama Theater named after M.S. Shchepkin.

Tour route: Grazhdansky Ave. 23 - Grazhdansky Ave. 33 - Grazhdansky Ave. 41 Grazhdansky Prospekt, 55 - Grazhdansky Prospekt, 61 - Sobornaya Square - Sobornaya St. 1B.

Program of a quest-tour "Artefacts of Belgorod"

12:00 - Poklonnyi cross in honour of Cyril and Methodius;

12:45 - Likhanov Children's Library;

13:10 - Monument to geodesist and Rooms of Weinbaum;

13:50 - Monument to S. Degtyarev;

14:15 - Municipal Cafe "Orion", lunch break;

15:10 - Alley of Friendship of Peoples;

15:35 - Cathedral Square and the M.S. Schepkin Drama Theater;

16:20 - Square at the M.S. Schepkin Drama Theater.

The duration of the tour is 4 hours and 45 minutes.

Groups from 6 to 20 people, from 2 to 6 teams.

Quest-excursion "Artefacts of Belgorod" consists of 7 stages, among which Stage 1 is its start, and Stage 7 is finish.

7 stages of the quest-excursion "Artefacts of Belgorod":

1. Memorial cross in honor of Cyril and Methodius.

2. Children's Library named after A.A. Likhanov.

3. Monument to geodesist and Rooms of Weinbaum

4. Monument to S. Degtyarev. 
5. Municipal Cafe "Orion" and the Alley of Friendship of Peoples.

6. Sobornaya Square and the Drama Theater named after M.S. Schepkin.

7. The square near the Shchepkin Drama Theater.

At each of the stages, a synthesis of excursion and game parts is supposed. During the transition from one stage to another, a general excursion part about the history of Belgorod is told.

In total, in the quest-excursion "Artefacts of Belgorod" there are 11 intellectual tasks; 8 tasks-games, one of which does not provide for points ("Acquaintance"); 3 tours to the objects of architectural heritage; 1 lunch break in the cafe "Orion".

At the end of the quest-excursion "Artefacts of Belgorod", the results of the teams' participation are counted and the winner by the greatest number of points is announced. The winning team is awarded with prizes. Those teams, which are not winners, are also awarded with incentive gifts.

Thus, cultural and educational tourism can be developed with such an innovative method as a quest excursion. This tourist product will be able to have a positive impact both on the individual person, the group gathered in a team of people, and in general on tourism as a sphere of activity. In such a way to cultural and educational objects can attract the attention of schoolchildren, young people and middle-aged people, as well as give a general discharge of physical and emotional states of the person that will have a positive impact on improving people's standard of living, getting positive emotions. New developed tourist product meets the requirements of tourists and is able to affect favorably the development of cultural and educational tourism and the economy of the region as a whole.

\section{REFERENCES}

BARCHUKOV I. S. Methods of scientific research in tourism: A textbook for universities. Moscow: Publishing Centre "Academy", 2008. 224 p.

BELGOROD Regional Centre for Children's and Youth Tourism and Excursions. [s.d.]. Available: http://www.belcdtur.ru/index.php/ekskursii/-ekskursionno-kraevedcheskieprogrammy. Access: 22 Jan. 2021.

BELGOROD. The Belgorod region in numbers in 2006: A brief statistical digest. Belgorodstat, 2007. $230 \mathrm{p}$.

EXCURSION routes in the Belgorod Region."Zolotaya Podkova". Available: https://zpodkova.tiu.ru/p6864004-ekskursionnye-marshruty-belgorodskoj.html. Access: 23 Mar. 2021. 
MATVEEVA, N. V. Role Play and WebQuest: A new look at the traditional. Secondary Vocational Education, n. 4, p. 45-47, 2014.

NIKOLAYEVA, N.V. Educational quest-projects as a method and means of developing students' information activity skills. Questions of Internet-education, n. 7, 2002. Available: http://vio.fio.ru/vio_07. Access: 28 Feb. 2021.

NOVIKOV, V. S. Innovations in tourism. Moscow: Publishing Centre "Academy", 2007. $208 \mathrm{p}$.

ROMANENKO V. V.; VASILYEVA, T. V. Heritage of Belogorye: Almanac. Belgorod: Belgorod Department of Culture of the Belgorod region, Belgorod State Historical and Local Museum, 2006. 172 p.

TOURIST BUREAU DOBROKHOT. School excursions. Available: https://Dobrokhot31.com/SHkolnyie_ekskursii Access: 18 Feb. 2021.

TOURIST COMPANY “KOLIBRI TOUR”. Reception in Belgorod. Electronic text data. Available: http://kolibritur31.ru/priem-v-belgorode/. Access: 21 Jan. 2021.

TOURIST COMPANY “TSENTER MIRA”. Rest according to the directions. Electronic text data. Available: https://centrmira.com/tours/tipy-turov/excursions/ Access: 24 Feb. 2021.

TOURIST FIRM “ACTIVE-TOUR”. Excursion tours across the Belgorod region. Available: http://aktiv-tour.ru/po-belgorodskoj-oblasti-chast-2/. Access: 19 Feb. 2021.

TRAVEL COMPANY “NIKA TOUR”. Reception in Belgorod. Available: http://www.nikatur31.ru/priem-v-belgorode/. Access: 23 Mar. 2021. 


\section{How to reference this article}

KHARKOVSKAYA, E. V.; POSOKHOVA, N. V.; EFREMOVA, N. V.; MIROSHNICHENKO, E. V. Analysis of the cultural and educational tourism development in the Belgorod Region. Revista on line de Política e Gestão Educacional, Araraquara, v. 25, n. esp. 6, p. 3550-3567, Dec. 2021. e-ISSN:1519-9029. DOI: https://doi.org/10.22633/rpge.v25iesp.6.16116

Submitted: 10/04/2021

Required revisions: $15 / 08 / 2021$

Approved: 20/11/2021

Published: $30 / 12 / 2021$

Processing and publication by the Editora Ibero-Americana de Educação. Correction, formatting, standardization and translation.

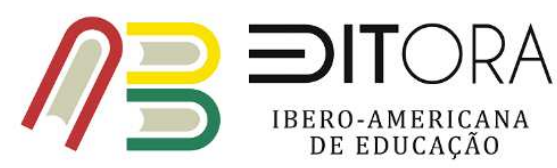

